\title{
Acerca de la imagen de tapa: Ritmos Primarios, la Subversión del Alma, de Hugo Aveta, 2013
}

About the Cover Image: Ritmos primarios, la subversión del alma (Primary Rhythms, the Subversion of the Soul), by Hugo Aveta, 2013

Sobre a imagem da capa: Ritmos primários, a subversão da alma, de Hugo Aveta, 2013

Responsables de la sección Prácticas artísticoculturales. Equipo editorial Aletheia aletheia@fahce.unlp.edu.ar

Universidad Nacional de La Plata, Argentina

Cita sugerida: Responsables de la sección Prácticas artístico-culturales. Equipo editorial Aletheia (2021).

Acerca de la imagen de tapa: Ritmos Primarios, la Subversión del Alma, de Hugo Aveta, 2013. Aletheia, 12(23), e111. https://doi.org/10.24215/18533701e111 


\section{IMAGEN 1}

Sin título (Hugo Aveta, 2013)

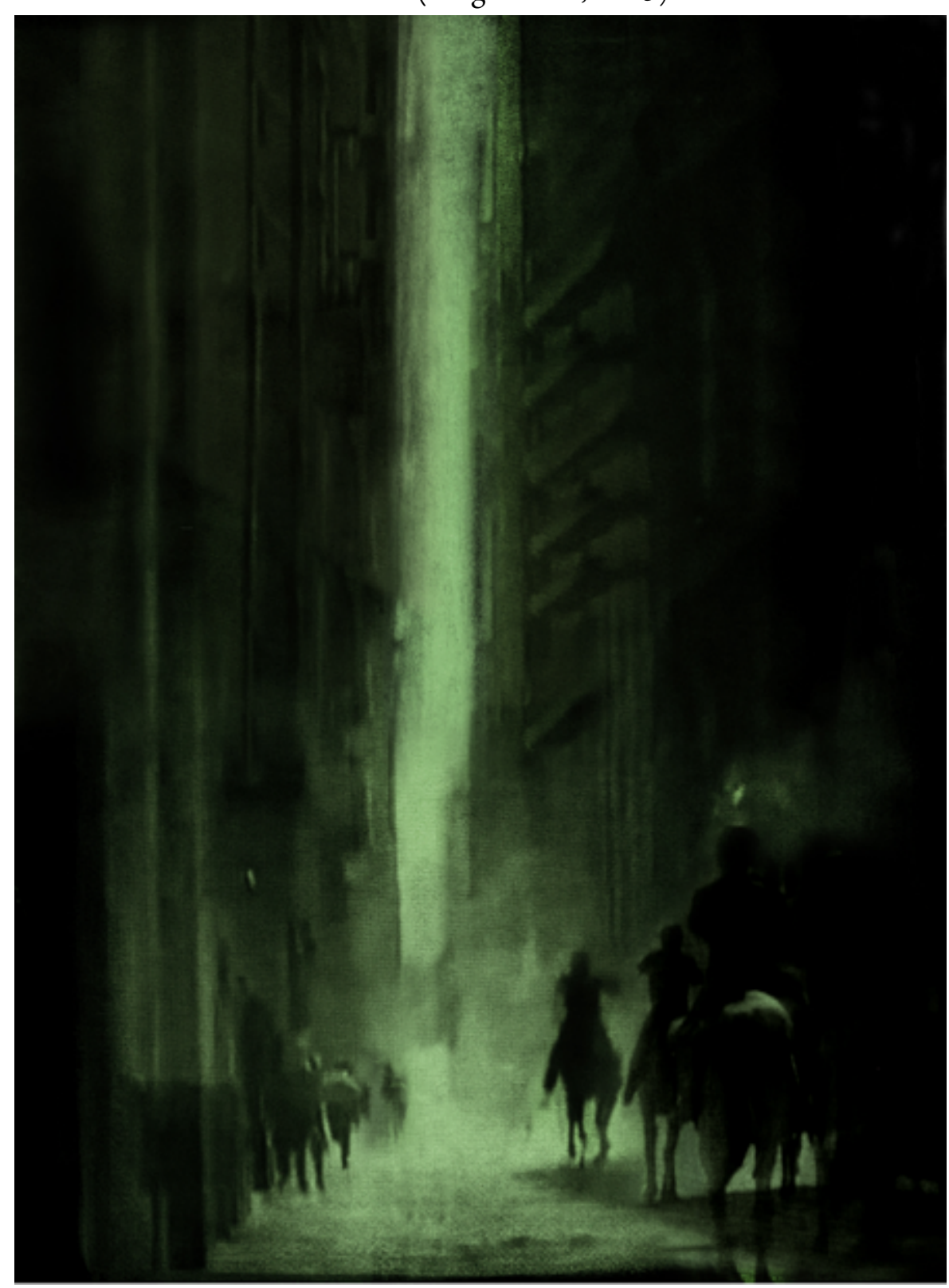

Hugo Aveta (Córdoba, Argentina, 1965) es artista visual, arquitecto y fotógrafo. Sus obras, reconocidas a nivel internacional y latinoamericano, han obtenido importantes premios y han sido presentadas en numerosas exposiciones de museos, incluido el Museo de Arte Moderno de Buenos Aires (MAMBA), el Museo de Arte Contemporáneo de Roma (MACRO), el Museo Nacional de Bellas Artes (MNBA), el Museo de Arte Contemporáneo de Salta (Argentina), el Museo de Arte Latinoamericano (MOMAA) en California, el Musée du Quai Branly en París (Bienal Photoquai) y en la MAISON ROUGE - Fondation Antoine de Galbert en París, así como en el MUNTREF Centro de Arte Contemporáneo, Hotel de Inmigrantes en Buenos Aires. Recientemente terminó su residencia en el Museo de Arte Contemporáneo MACVAL, París, Francia, donde presentó una instalación monumental titulada "La fascinación de la falla". También su obra “Tracción a sangre” forma parte del Parque de la Memoria, en Buenos Aires. 
Sus temas de trabajo abordan la Historia, la memoria, el tiempo y los archivos, a través de instalaciones, videos y fotografías. La serie titulada Ritmos Primarios, la Subversión del Alma, a la que pertenece la imagen de tapa, fue realizada en el año 2013 y exhibida en 2014 en Ro-Galería de Arte, Buenos Aires ${ }^{1}$. En ella Aveta explora los procedimientos de la fotografía para producir nuevas imágenes sobre las jornadas del 19 y 20 de diciembre del 2001.

Mediante un procedimiento artesanal que tiene como escenario el laboratorio, el artista se vale de fragmentos de videos que registraron las manifestaciones y represiones callejeras, y los dispara sobre un lienzo cubierto por una emulsión fotosensible que fotografía la imagen pocos segundos antes de que desaparezca. Obtiene así imágenes de estos fotogramas que luego filma con una cámara infrarroja, motivo por el que las imágenes adoptan ese tono verdoso particular.

A partir de un Procedimiento alquimico, como lo denomina Almada, curadora de la muestra, Aveta produce nuevas fotografías deteniendo el tiempo y creando un nuevo espacio de representación, en el que las imágenes se multiplican. "En su técnica recobra algo del oficio perdido del laboratorio, aunque procediendo a la inversa. Las imágenes ya no emergen de la emulsión sino que se proyectan sobre ella" (Almada, 2014). Con esta operación nos permite, además, ver en la oscuridad. Sus obras son también un modo de acercarnos a ese episodio de la historia reciente, echando luz sobre las manifestaciones y la represión oscura, permitiendo que emerjan nuevos significados. La muestra cuenta además con un video, que puede verse en la página web del $\operatorname{artista}^{2}$.

Los videos proceden de diferentes archivos y remiten a imágenes icónicas de aquel ciclo de protestas, que fue punto de inflexión de la crisis económica, política y social. A partir de estos, Aveta produce nuevas imágenes para narrar aquellas jornadas. Al observarlas, reconocemos vestigios de algo que sucedió y nos es familiar, al tiempo que los escenarios y sus actores, desdibujados, se nos vuelven extraños. Fortuny (2017) las denomina "imágenes-desvío" que tensionan la relación documental-fotográfico, mostrando el procedimiento del dispositivo fotográfico y abriendo el pliegue del tiempo. La autora destaca cómo las memorias sobre aquellas jornadas quedaron muy asociadas a las imágenes televisivas. Partiendo de estos documentos históricos, el artista produce nuevas memorias fotográficas, y con ellas nuevos sentidos sobre esos episodios. "Estas imágenes son el producto de operaciones combinatorias que, asentadas en la supuesta verdad del documento, reorganizan y multiplican los significados y, al hacerlo, modifican su origen y su destino. A menor nitidez mayor significación. Las imágenes pierden capacidad de representación para ganar capacidad de evocación y activar el poder de la reminiscencia" (Almada, 2014). Las obras adquieren además cierto carácter pictórico y en un primer acercamiento pueden parecernos pinturas, por la paleta y las texturas que adoptan.

La imagen seleccionada para la tapa del Dossier (Imagen 1) consiste en un plano vertical muy bien logrado, en el que la luz se extiende por el punto de fuga, exaltándose un paisaje porteño de edificios altos y pequeñas calles. Las personas corren por la izquierda, la policía reprime en sus caballos por la derecha y en el medio pueden verse los gases. Como señala Fortuny "es difícil olvidar las visiones del obelisco rodeado de llamas, los caballos de la infantería sobre los cuerpos de los manifestantes, los torsos desnudos de los manifestantes, los lugares emblemáticos - tanto por su dimensión política como turística - como la Plaza de Mayo y el Congreso Nacional convertidos en arenas de la batalla y rodeados de espeso humo negro" (Fortuny, 2017, p. 2). 


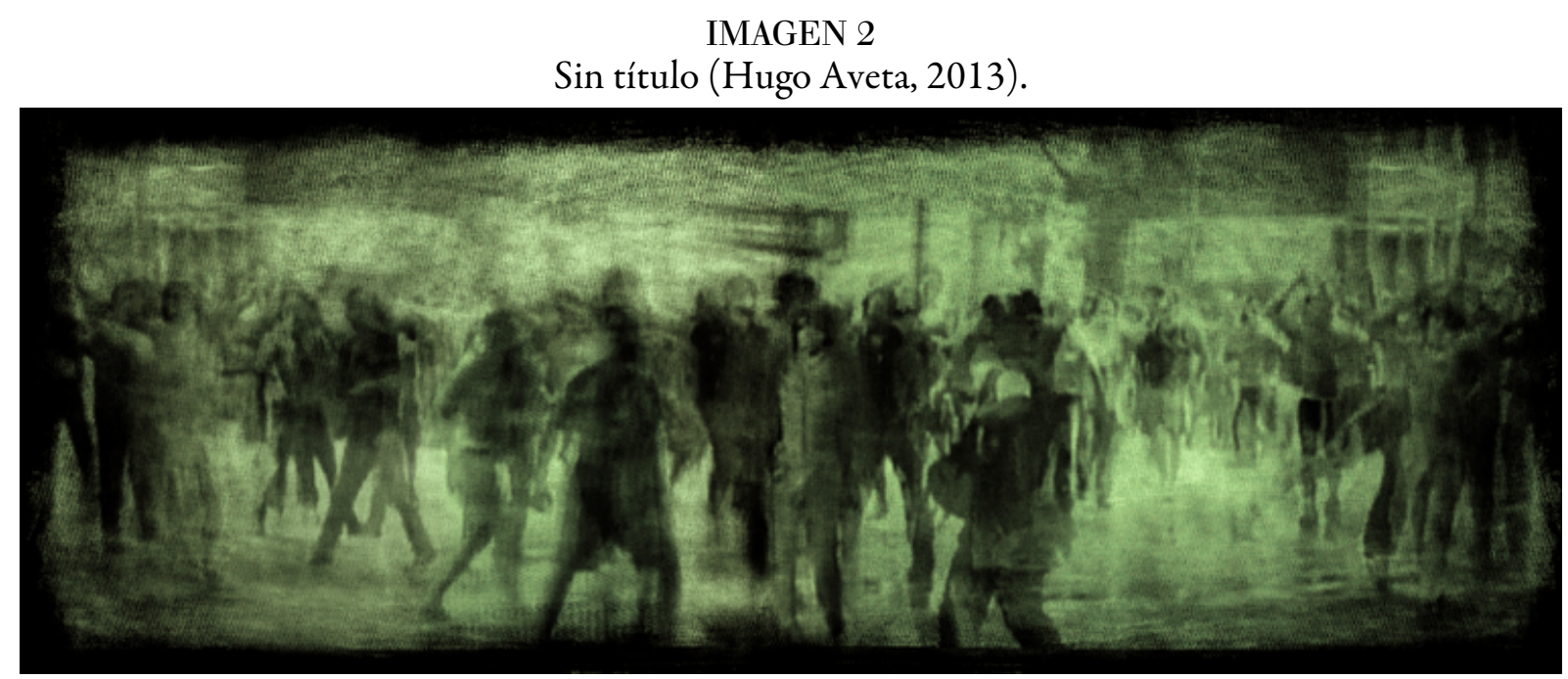

En la Imagen 2, apaisada, vemos unas figuras humanas que nos remiten a una línea de resistencia. Detrás de ella podemos advertir una multitud formando en un continuo las barricadas. Las figuras del centro resaltan sobre un plano profundo, pudiendo distinguirse algunos brazos levantados y piernas en movimiento: cuerpos que se encuentran dispuestos a la lucha.

\section{IMAGEN 3}

Sin título (Hugo Aveta, 2013)

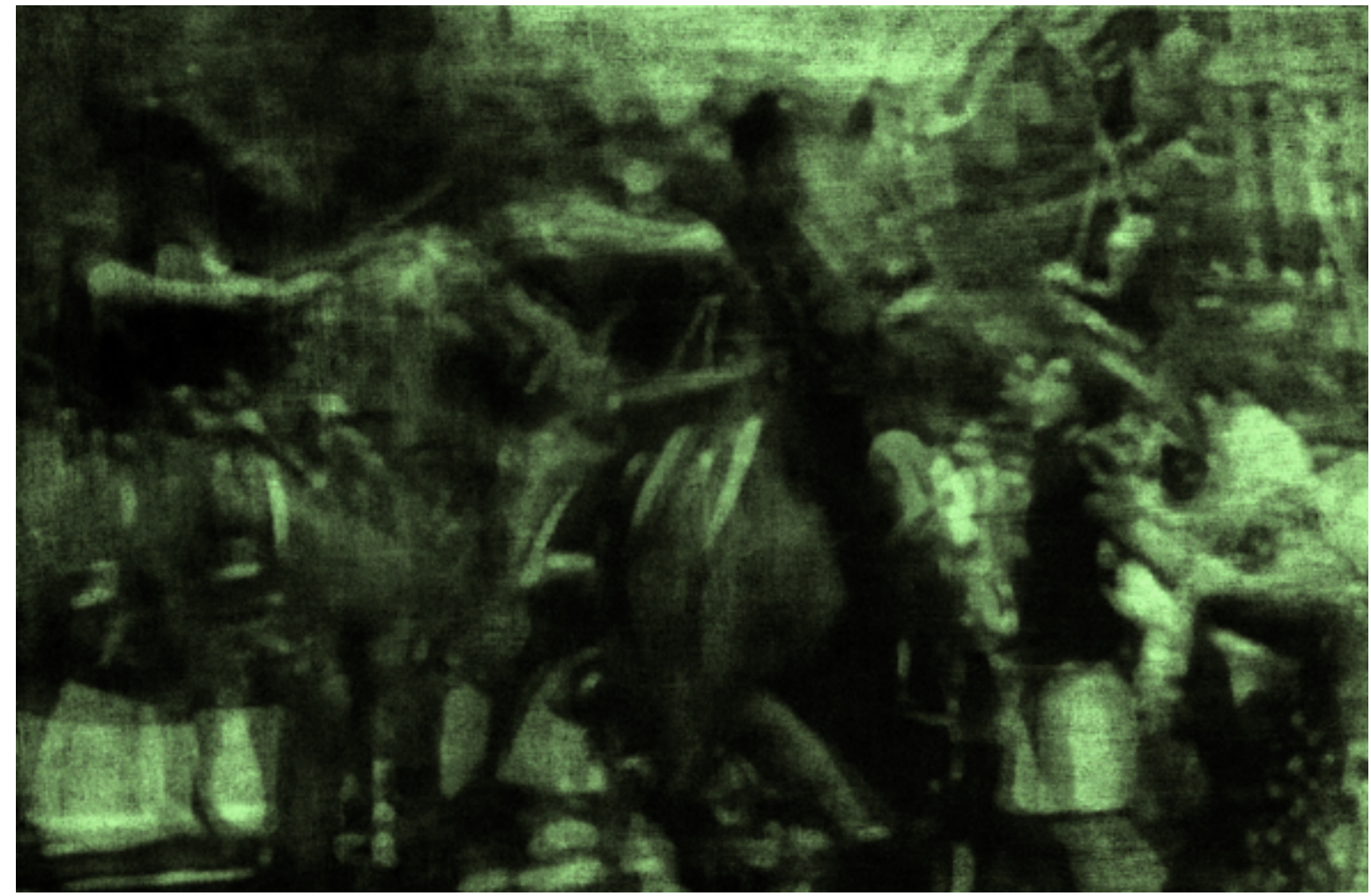

La Imagen 3 nos interpela desde una representación icónica de aquellos días, el momento en el que la Policía Montada reprime a las Madres de Plaza de Mayo. Esta imagen se constituyó en una de las más emblemáticas de las jornadas, en la que contrasta la presencia de las mujeres con pañuelo enfrentando la 
represión policial desde los caballos. Sin dudas los caballos forman parte de las representaciones recurrentes sobre aquellos días, por lo que su presencia nos remite rápidamente a las escenas de la represión.

Oscuridad, represión, corridas. Luz, protesta y barricada. Las escenas de Ritmos Primarios, la Subversión del Alma, configuran imágenes espectrales y memorias que punzan por aparecer. Son imágenes que surgen del trabajo con la materialidad del tiempo. Un tiempo que se desmonta para volver a anudarse en nuevos sentidos sobre un pasado de un inusitado presente.

\section{REFERENCIAS}

Almada, A. (2014). Leer el tiempo: texto curatorial. RO Galería de Arte (página web). Recuperado de http://www.a rsomnibus.com.ar/web/muestra/leer-el-tiempo

Fortuny, N. (2017) Leer el tiempo: memorias fotográficas de la crisis argentina de 2001. Revista Photo \& Documento, 4, 2017. ISSN 2448-1947. Recuperado de http://gpaf.info/photoarch/index.php?journal=phd\&page=article\&o $\mathrm{p}=$ view\&path\%5B $\% 5 \mathrm{D}=172$

Página Web Hugo Aveta: https://www.hugoaveta.com/

\section{Notas}

1 También fue exhibida ese año en Nextgalerie, París, Francia. El video que forma parte de la muestra fue además seleccionado para participar en LOOP Barcelona 2014.

2 Video de la muestra: https://www.hugoaveta.com/video 